\title{
An Economic Analysis of Coconut Farming in Karur District of Tamil Nadu, India
}

\author{
C. Vinodhini ${ }^{1 *}$ and K.V. Deshmukh ${ }^{2}$ \\ ${ }^{1}$ Agricultural Economics, Department of Agricultural Economics, Institute of Agricultural \\ Sciences, Banaras Hindu University, Varanasi-221005, India \\ ${ }^{2}$ Department of Agricultural Economics, VNMKV, Parbhani, India \\ *Corresponding author
}

\begin{tabular}{|c|c|}
\hline \multicolumn{2}{|r|}{ A B S T R A C T } \\
\hline & \multirow{5}{*}{$\begin{array}{l}\text { This study attempts to examine the socio economic profile and economics of coconut } \\
\text { production in Karur district of Tamil Nadu. A sample of } 60 \text { farmers was selected through } \\
\text { multistage sampling technique. The major finding of economic analysis revealed that, most } \\
\text { of coconut growers were from middle age and had a family size between } 4-6 \text {.The farmers } \\
\text { in the study area are poorly educated. Regarding occupation out of } 80 \text { cultivators, } 62 \text { were } \\
\text { having farming as their main occupation, while } 08 \text { and } 10 \text { cultivators were having business } \\
\text { and service as their main occupation, respectively. The average size of land holding of } \\
\text { coconut growers was } 2.82 \text { ha. An average amount of Rs. } 228082.40 \text { was required for } \\
\text { establishing one hectare of coconut orchard and it was observed that per hectare cost of } \\
\text { cultivation of coconut orchard was worked out to Rs. } 92272.75 \text {. Regarding profitability of } \\
\text { coconut cultivation, in study area cultivation of coconut is a profitable enterprise, as } \\
\text { indicated by benefit cost ratio (1.39). }\end{array}$} \\
\hline & \\
\hline $\begin{array}{l}\text { Coconut, Farming, } \\
\text { Analysis. }\end{array}$ & \\
\hline Article Info & \\
\hline $\begin{array}{l}\text { Accepted: } \\
\text { 12 October } 2017 \\
\text { Available Online: } \\
10 \text { December } 2017\end{array}$ & \\
\hline
\end{tabular}

\section{Introduction}

Agriculture has been playing a predominant role in the economic development of all developed and developing countries.

Ever since India's independence, agriculture in India has taken major strides owing to the varietals and agronomic interventions of agricultural research and the resourcefulness of the farming community.

The Green Revolution of the 1960's ushered rapid increase in food crop production such as wheat, rice and other cereals. Efforts were also taken to achieve similar increases in nonfood crop production viz., coconut, groundnut, sugarcane and cotton. The coconut palm, botanically known as "Cocus nucifera" is unique among horticulture crops raised in India because of the diverse uses of the coconut products in everyday life. So far nearly 360 uses have been reported. Every part of the coconut tree is of great utility and hence it is rightly called as 'Kalpaviriksha' or the 'Tree of Heaven'.

Coconut palm provides food security and livelihood to large size of population in the world particularly in Asian Pacific Countries. It is estimated that about 12 million people in India are dependent on the coconut sector in areas of cultivation, processing and trading activities. 
The main objectives of this study includes to discuss the personal profile of farmers in the sample Districts. The average per hectare cost of production of coconut in the study area to be verified; And to estimate returns realized by the growers in the study area;

\section{Sampling technique and data description}

The data was collected for the research during November - December 2015 with multistage sampling technique. Karur district was purposively selected as study area in the first stage, in the second stage Manmangalam tehsil was selected on the basis of higher area under coconut. In third stage eight villages were selected from the selected tehsil on the basis of highest area under coconut production. And in fourth stage 10 coconut growers were selected randomly from each village. Thus 80 growers were selected with equal distribution.

\section{Results and Discussion}

\section{Socio economic status of coconut growers}

The socio economic characteristics of the sample farmers with respect to age, educational score, occupation, family size and livestock numbers is presented in Table 1 . The results revealed that most of coconut growers were from middle age which accounts for 52.82 years. Education level of coconut farmers were 1.35 scores. This indicated that the farmers in the study area are poorly educated. Family size was 4.48 in numbers with 2.21 male and 2.27 female members. Most of the coconut growers had a family size between 4 to 6.Regarding occupation out of 80 cultivators, 62 (77\%) were having farming as their main occupation, while $08(10 \%)$ and $10(12 \%)$ cultivators were having business and service as their main occupation, respectively. The average size of land holding of coconut growers was 2.82 ha. In regard to cropping intensity, 100.71 cropping intensity was observed on coconut grower's farm. Results revealed that gross cropped area was 2.82 hectares. It was observed that in kharif, area under rice was highest as 7.80 per cent.

While in rabi season, the highest area under pulses which was 1.06 per cent. The net sown area on farm was 2.80 hectares and double crop area was 0.02 hectares. It was observed that total livestock was 2.32 .

\section{Establishment of coconut orchard}

Every long duration horticultural crop has two phases viz., i) Establishment phase or development phase and ii) Production phase. The coconut orchard starts bearing generally after five years from the year of plantation. The coconut growers have to invest considerable amount in the form of inputs for establishment of the coconut orchard up to its bearing stage. This period is called as "gestation period".

\section{Operation wise labour utilization}

Table 2 reveals that total per hectare labour utilized for establishing coconut orchard was 416.59 man days, out of which maximum i.e. 104.09 man days $(24.98 \%)$ were utilized for irrigation/hand watering followed by 70.11 man days (16.82\%) for manuring and fertilization of young plants. As regards year wise total labour utilization during five years period, it was found that 206.95 man days (49.67\%) were used in the first year of the plantation. The labour utilization decreased from second year 71.87 man days $(17.25 \%)$ to fifth year 32.80 man days $(7.87 \%)$. 
Table.1 Socio economic status of coconut growers

\begin{tabular}{|c|c|c|c|}
\hline SNO & Particulars & $N=80$ & Percentage \\
\hline$\overline{1 .}$ & Age & 52.82 & - \\
\hline 2. & Education & 1.35 & - \\
\hline \multirow[t]{12}{*}{3.} & \multicolumn{3}{|l|}{ Occupation } \\
\hline & Main (No of Growers) & & \\
\hline & Agriculture & 62 & 72.00 \\
\hline & Business & 08 & 10.00 \\
\hline & Service & 10 & 12.00 \\
\hline & Total & 80 & 100.00 \\
\hline & Subsidiary (No of Growers) & & \\
\hline & 1.Agriculture & 18 & 22.50 \\
\hline & 2.Business & 9 & 11.25 \\
\hline & 3.Service & 13 & 16.25 \\
\hline & 4.Without Subsidiary & 40 & 50.00 \\
\hline & Total & 80 & 100.00 \\
\hline \multirow[t]{6}{*}{4.} & \multicolumn{3}{|l|}{ Family Size (No.) } \\
\hline & Male & 2.21 & 49.33 \\
\hline & Female & 2.27 & 50.64 \\
\hline & Total & 4.48 & 100.00 \\
\hline & Working Members & 2.46 & 54.91 \\
\hline & Non Working Members & 2.02 & 45.09 \\
\hline
\end{tabular}

Table.2 Operation wise per hectare labour required for establishment of coconut orchard

\begin{tabular}{|c|c|c|c|c|c|c|c|}
\hline$\overline{\mathrm{S} \mathrm{No}}$ & Operations & $1^{\text {st }}$ year & $2^{\text {nd }}$ year & $3^{\text {rd }}$ year & $4^{\text {th }}$ year & $5^{\text {th }}$ year & Total \\
\hline 1 & Land preparation & 58.14 & -- & -- & -- & -- & $\begin{array}{r}58.14 \\
(13.95)\end{array}$ \\
\hline 2 & Layout leveling & 12.55 & -- & -- & -- & -- & $\begin{array}{l}12.55 \\
(3.01)\end{array}$ \\
\hline 3 & $\begin{array}{l}\text { Digging of pits filling } \\
\text { with soil }\end{array}$ & 10.29 & -- & -- & -- & -- & $\begin{array}{l}10.29 \\
(2.47)\end{array}$ \\
\hline \multirow[t]{3}{*}{4} & Planting & & & & & & \\
\hline & $\begin{array}{l}\text { i)Preparation of basin } \\
\text { ii) Providing support }\end{array}$ & 9.20 & -- & -- & -- & -- & $\begin{array}{l}9.20 \\
(2.20)\end{array}$ \\
\hline & $\begin{array}{l}\text { and shade } \\
\text { Fencing and repairing to }\end{array}$ & 11.94 & 6.88 & 5.29 & -- & -- & $\begin{array}{l}24.17 \\
(5.78)\end{array}$ \\
\hline 5 & $\begin{array}{l}\text { fence } \\
\text { Irrigation }\end{array}$ & 11.26 & 4.53 & 4.54 & 3.89 & 3.29 & $\begin{array}{l}27.51 \\
(6.60)\end{array}$ \\
\hline 6 & Interculturing operation & 52.67 & 25.85 & 25.57 & -- & -- & $\begin{array}{l}104.09 \\
(24.98)\end{array}$ \\
\hline 7 & Manuring and & 15.12 & 9.09 & 10.59 & 7.85 & 8.05 & $\begin{array}{c}50.70 \\
(12.17)\end{array}$ \\
\hline 8 & $\begin{array}{l}\text { fertilization } \\
\text { Plant protection }\end{array}$ & 12.19 & 13.33 & 14.43 & 15.07 & 15.09 & $\begin{array}{c}70.11 \\
(16.82)\end{array}$ \\
\hline \multirow[t]{2}{*}{10} & Mulching & 4.65 & 4.98 & 5.12 & 5.52 & 5.25 & $\begin{array}{l}25.52 \\
(6.12)\end{array}$ \\
\hline & Others & 4.49 & 3.49 & 2.87 & -- & -- & $\begin{array}{l}10.85 \\
(2.60)\end{array}$ \\
\hline \multirow{2}{*}{11} & Total & 4.45 & 3.72 & 2.55 & 1.68 & 1.12 & $\begin{array}{l}13.52 \\
(3.24)\end{array}$ \\
\hline & & $\begin{array}{l}206.95 \\
(49.67)\end{array}$ & $\begin{array}{l}71.87 \\
(17.25)\end{array}$ & $\begin{array}{l}70.96 \\
(\mathbf{1 7 . 0 5})\end{array}$ & $\begin{array}{l}34.01 \\
(8.16)\end{array}$ & $\begin{array}{c}32.8 \\
(7.87)\end{array}$ & $\begin{array}{r}416.59 \\
(100.00)\end{array}$ \\
\hline
\end{tabular}




\section{Int.J.Curr.Microbiol.App.Sci (2017) 6(12): 1566-1573}

Table.3 Per hectare values of inputs used for establishment of coconut orchard (Rs.)

\begin{tabular}{|c|c|c|c|c|c|c|c|c|}
\hline \multirow[t]{2}{*}{ S.No. } & \multirow[t]{2}{*}{ Particulars } & \multirow[t]{2}{*}{$1^{\text {st }}$ year } & \multirow[t]{2}{*}{$2^{\text {nd }}$ year } & \multirow[t]{2}{*}{$3^{\text {rd }}$ year } & \multirow[t]{2}{*}{$4^{\text {th }}$ year } & \multirow[t]{2}{*}{$5^{\text {th }}$ year } & \multicolumn{2}{|c|}{ Total } \\
\hline & & & & & & & Amount (Rs.) & Per cent \\
\hline \multirow[t]{4}{*}{1} & Labour & & & & & & & \\
\hline & a) Family labour & 30366.00 & 10237.80 & 10242.00 & 4950.60 & 4894.10 & 60690.60 & 26.67 \\
\hline & b) Hired labour & 26790.00 & 9228.00 & 9151.80 & 4244.80 & 4000.80 & 53474.40 & 23.49 \\
\hline & Total & 57156.00 & 19465.80 & 19393.80 & 9254.40 & 8895.90 & 114165.00 & 50.16 \\
\hline 2 & Seedlings & 8010.00 & 360.00 & -- & -- & -- & 8370.00 & 3.67 \\
\hline 3 & Manures & 2943.00 & 4275.00 & 5437.50 & 6750.00 & 6750.00 & 26155.50 & 11.49 \\
\hline 4 & Fertilizers & 3480.91 & 6961.87 & 9734.87 & 12690.00 & 12690.00 & 45557.65 & 20.02 \\
\hline 5 & Plant protection chemicals & 712.00 & 898.50 & 925.00 & 1258.00 & 1436.50 & 5230.00 & 2.29 \\
\hline 6 & Support and providing shade & 822.50 & 470.00 & 411.25 & -- & -- & 1703.75 & 0.74 \\
\hline 7. & Mulching & 525.00 & 475.00 & 350.50 & -- & -- & 1350.50 & 0.59 \\
\hline \multirow[t]{3}{*}{8.} & Fencing and repairing to fence & 17550.00 & 3500.00 & 2500.00 & 1000.00 & 1000.00 & 25550.00 & 11.22 \\
\hline & Total & 91199.41 & 36406.17 & 38752.92 & 30952.40 & 30772.40 & 228082.40 & 100.00 \\
\hline & & $(39.98)$ & $(15.96)$ & $(16.92)$ & $(13.57)$ & $(13.49)$ & $(100.00)$ & \\
\hline
\end{tabular}

(Figures in the parentheses indicates percentage to total) 
Table.4 Per hectare cost of cultivation of coconut orchard

\begin{tabular}{clcc}
\hline Sr. No. & \multicolumn{1}{c}{ Particulars } & Value & Per cent \\
\hline 1 & Hired human labour & & \\
& a) Male & 5205.00 & 5.64 \\
& b) Female & 4778.40 & 5.17 \\
& Total & 9983.40 & 10.81 \\
2 & Manures & 5970.00 & 6.46 \\
3 & Fertilizers & & \\
& N & 4320.00 & 4.68 \\
& P & 4536.00 & 4.91 \\
& K & 837.00 & 0.90 \\
4 & Plant protection & 520.00 & 0.56 \\
5 & Interest on working capital @ 11 \% & 2878.30 & 3.11 \\
6 & Land revenue & 125.00 & 0.13 \\
7 & Depreciation on implements & 1712.81 & 1.85 \\
& Cost- A & 30882.51 & 33.46 \\
8 & Rental value of land & 21450.00 & 23.24 \\
9 & Interest on fixed capital @ 10\% & 1732.00 & 1.87 \\
10 & Amortization cost & 27369.84 & 29.66 \\
& Cost- B & 81434.35 & 88.25 \\
11 & Family labour & & \\
& a)Male & 6492.00 & 7.03 \\
& b)Female & 4346.40 & 4.71 \\
& Total & 10838.40 & 11.74 \\
& Cost- C & 92272.75 & 100.00 \\
\hline
\end{tabular}

Table.5 Per hectare yield and returns from coconut orchard

\begin{tabular}{|c|c|c|}
\hline Sr. No. & Particulars & Value \\
\hline 1. & No. of bearing trees & 175 \\
\hline \multirow[t]{3}{*}{2.} & Main produce: & \\
\hline & Yield of nuts & 12615 \\
\hline & Price per nut & 10.00 \\
\hline A) & Value of nuts (Rs.) & $\begin{array}{c}126150.00 \\
(98.01)\end{array}$ \\
\hline \multirow[t]{7}{*}{3.} & By-product: & \\
\hline & Yield of spathe & 2100 \\
\hline & Price per spathe & 0.50 \\
\hline & Yield of leaf base & 1000 \\
\hline & Price per base & 0.50 \\
\hline & Yield of midrib & 1000 \\
\hline & Price per midrib & 1.00 \\
\hline \multirow[t]{2}{*}{ B) } & Value of by-products (Rs.) & $\begin{array}{c}2550.00 \\
(1.99)\end{array}$ \\
\hline & Total returns A + B & 128700.00 \\
\hline
\end{tabular}


Table.6 Per hectare profitability of coconut orchard

\begin{tabular}{clc}
\hline S. No. & Particulars & Value \\
\hline 1. & Gross returns (Rs.) & 128700.00 \\
2. & Costs (Rs.) & \\
& a) Cost A & 30882.51 \\
& b) Cost B & 81434.35 \\
& c) Cost C & 92272.75 \\
$3 . \quad$ Profit at (Rs.) & 97817.49 \\
& a) Cost A & 47265.65 \\
& b) Cost B Cost C & 36427.25 \\
& a) C Cefit cost ratio & 1.39 \\
\hline
\end{tabular}

Among the total per hectare labour utilization, the composition of male and female was 236.39 man days $(56.74 \%)$ and 180.20 man days $(43.26 \%)$ respectively. This showed that, throughout the establishment period the utilization of male labour was more than the female labour.

\section{Cost of Establishment for Coconut Orchard}

It is revealed from Table 3 that, per hectare total cost incurred in a period of five years for establishing coconut orchards worked out to Rs. 228082.40.Out of this investment, maximum cost incurred on labour 50.16 per cent (Rs.114165).

Further, it is also observed from Table 3 that, out of total cost of establishment 39.98 per cent (Rs. 91199.41) was incurred during the first year, 15.96 per cent (Rs. 36406.17) during second year, 16.92 per cent (Rs. 38752.92) during third year, 13.57 per cent (Rs. 30772.40) during fourth year and 13.49 per cent (Rs. 228082.40) during fifth year.

This indicated that maximum expenditure was incurred during the first year and it declined in subsequent years.

Similar findings were also reported by Mabel Sulochana (2009) while studying production and marketing of coconut with special reference to Kanyakumari district. Shinde (2007) reported economics of production and marketing of fig in Maharashtra. He revealed that per hectare establishment cost of orchard was Rs. 124955.

\section{Cost of cultivation of coconut orchard}

The per hectare item wise cost incurred for the cultivation of coconut orchard was worked out and presented in Table 4. It is observed that, per hectare total cost of maintenance of coconut orchard (cost- C) worked be Rs. 92272.75, out of which share of cost- A was 33.46 per cent and that of costB was 88.25 per cent.

Among the different important items of cost, rental value of land shared 29.30 per cent of the total cost. The maximum cost $(32.29 \%)$ was incurred on amortization.

Bansode (2001) reported that amortized establishment cost accounted for 7.49 per cent. The contribution of other items of cost ranged from 0.13 per cent for land revenue to 11.74 per cent for family labour.

Similar findings were also reported by Chinniah and Suresh (2013) while studying economic analysis of coconut cultivation in Tamil Nadu. 


\section{Yield, returns and profitability}

The gross returns included the value of raw nut and value of by-products. The results of the analysis are presented in Table 5. It is observed from Table 5 that, per hectare gross returns realized were Rs. 128700 from coconut orchard. This showed that returns from main produce (raw nuts) 98.01 per cent and remaining proportion $(1.99 \%)$ of returns was obtained from by-products of coconut tree. Per hectare gross returns of coconut were higher because, per hectare number of trees (175), yield of nuts per tree (83.71), as well as price per raw nut (Rs. 10/nut). Regarding byproduct, coconut growers harvesting three main by products are spathe, leaf base, midribs. Yield of spathe, leaf base, midribs per hectare is $2100,1000,1000$ respectively. And price per unit of those by products were $0.50,0.50,1.00$ rupees respectively.

The per hectare profitability of coconut orchard is presented in Table 6. It is seen from Table 6 that, per hectare gross returns received were Rs. 92272.75. Profit at different cost levels i.e. cost A, cost B, cost C of coconut was 97817.49, 47265.65, 36427.25 respectively.

This was because of the higher productivity and price received per $\mathrm{kg}$ of raw nut. Per hectare net returns obtained was Rs 36427.25 and the benefit cost ratio was 1.39

As coconut is also a significant foreign exchange earner and source of income and employment to millions of people this study has been undertaken. Another aim is, mainly to help the Government to take up policy decisions and formulate suitable schemes and programmes to ameliorate socio-economic conditions of the coconut cultivators. The present study has brought into focus, various issues relating to socio economic status and production of coconut.
The following conclusions are drawn from the present study.

Coconut is the perennial cash crop which is having gestation period of five years. In this period to establish a coconut orchard growers have to incur huge expenditure. It is observed from the study that, on an average an amount of Rs. 228082.40 was required for establishing one hectare of coconut orchard.

In establishing a coconut orchard highest amount that is 50.16 per cent was incurred on labour wages. Out of total establishment cost, 39.98 per cent was incurred during the first year, 15.96 per cent during second year, 16.92 per cent during third year, 13.57 per cent during fourth year and 13.49 per cent during fifth year. This indicated that, maximum expenditure was incurred during the first year.

Regarding cost of cultivation it was observed that per hectare cost of cultivation of coconut orchard was worked out to Rs. 92272.75. Out of which share of cost 'A' was 33.46 per cent and cost ' $\mathrm{B}$ ' was 88.25 per cent.

Regarding profitability of coconut cultivation, in study area the cultivation of coconut is a profitable enterprise, as indicated by benefit cost ratio (1.39).

\section{References}

Bharath Kumar, T.P., T.S. Sukanya, R.B. Belli., S. Shashikumar and R. Girish. (2014). Socio - economic Profile, Knowledge gain and Problem faced by Coconut growers of Chikmagalur district of Karnataka state. International Journal of Research in Humanities, Arts and Literature., Vol. 2(6): 15-20p.

Chinniah, M and G. Suresh. 2013. Coconut Marketing in Coimbatore. Indian Journal of Research., 3(5).

Mabel Sulochana, R. 2009. Production and 
Marketing of Coconut with Special Reference to Kanyakumari District. Thesis submitted to Research Centre and Post Graduate Department of Commerce, Scott Christian College Nagercoil, Kanyakumari District, Tamil Nadu, India.

Periasami. 2015. Problems And Prospects Of Coconut Cultivation in Erode District. International Multidisciplinary
Research Journal. 4(11).

Saravanan. 2013. A study on Production and Marketing constrains of farmers in Coimbatore district. Journal of Arts, Science \& Commerce. 4(1): 67-77p.

Sivanesan. R. and S. Prabin, 2013. Problems and Prospects of Coconut Industries in Kanyakumari district of Tamil Nadu. International Journal of Management. 4(6): 135-144.

\section{How to cite this article:}

Vinodhini, C. and Deshmukh, K.V. 2017. An Economic Analysis of Coconut Farming in Karur District of Tamil Nadu. Int.J.Curr.Microbiol.App.Sci. 6(12): 1566-1573. doi: https://doi.org/10.20546/ijcmas.2017.612.176 